\title{
Frequent semen collection and sperm reserves of the male Angora goat (Capra hircus)
}

\author{
A. J. Ritar ${ }^{1 *}$, G. Mendoza ${ }^{2}$, S. Salamon ${ }^{1}$ and I. G. White ${ }^{2}$ \\ Departments of ${ }^{1}$ Animal Science and ${ }^{2}$ Veterinary Physiology, University of Sydney, Sydney, \\ New South Wales 2006, Australia
}

\begin{abstract}
Summary. Semen was collected from six mature and sexually rested Angora bucks at one-hour intervals five times a day on each of 5 consecutive days in the breeding season. There was a marked decline in semen volume $(P<0.001)$, sperm concentration $(P<0.05)$ and number of spermatozoa $(P<0.001)$ on consecutive days. Successive ejaculates within days differed only in number of spermatozoa $(P<0.001)$. The following year at the beginning of the breeding season, the weights of testes and epididymides and the reserves of spermatozoa in these parts were examined after slaughter of the six bucks. The mean number of spermatozoa in the paired testes, capita, corpora and caudae of the epididymides were $(22 \cdot 8 \pm 1 \cdot 24) \times 10^{9},(9 \cdot 4 \pm 1 \cdot 19) \times 10^{9},(3 \cdot 4 \pm 0.22) \times$ $10^{9}$ and $(35 \cdot 0 \pm 2 \cdot 21) \times 10^{9}$, respectively. Epididymal reserves of spermatozoa were correlated with testicular weight $(r=0.50, P=0.01)$ and number of spermatozoa in the testes $(r=0.42, P=0.07)$, but not with epididymal weight. The daily production of spermatozoa per animal in the breeding season was estimated to be $4.0-6.4 \times 10^{9}$.
\end{abstract}

Keywords: libido; semen collection; sperm reserves; Angora goat

\section{Introduction}

Genetic improvement of farm animals relies on the intensive use of a few superior males either for natural mating or in artificial insemination programmes. The production of mohair from Angora goats may be increased through selective breeding of does with bucks exhibiting valuable fibre characteristics. However, libido, sperm production and other sexual characteristics may limit the extent to which bucks can be used for breeding.

It is possible to estimate the testicular production of spermatozoa indirectly on the basis of high correlations between traits of reproductive tracts (rabbit: Orgebin-Crist, 1968; boar: Kennelly \& Foote, 1964; bull: Almquist \& Amann, 1961; Weisgold \& Almquist, 1979; ram: Lino, 1972; Lino \& Braden, 1972). For example, there is a good correlation between the number of spermatozoa stored in the genital tract and the testicular production of spermatozoa in the ram (Ortavant, 1958; Lino, 1972). Partial sperm depletion by ejaculation also gives an estimate of the daily sperm production in the bull (Almquist \& Amann, 1961) and the ram (Lino \& Braden, 1972).

Sperm reserves in the reproductive tract were calculated for dairy bucks of various breeds (Fielden \& Berker, 1964) and for Indian bucks (breed unspecified: Jindal \& Panda, 1980). Fielden \& Berker (1964) also conducted trials on semen depletion by ejaculation, but came to no conclusions about the daily output of spermatozoa. No data are available on these sexual characteristics in Angora bucks.

In this study, Angora bucks were used for frequent semen collection by artificial vagina in the breeding season at the expected time of greatest output of spermatozoa. The reproductive tracts

*Present address: Animal Production Branch, Department of Primary Industry, PO Box 180, Kings Meadows, Tasmania 7249, Australia. 
were removed after slaughter of the animals at the beginning of the following breeding season, when bucks attain peak testicular development (Ritar, 1991), and the reserves of spermatozoa were examined.

\section{Materials and Methods}

\section{Collection and examination of semen}

Semen was collected with an artificial vagina from six mature and sexually rested Angora bucks on 5 consecutive days in April and May (autumn, Southern Hemisphere). Each buck was given five opportunities to serve over 5 h (one service $\mathrm{h}^{-1}$ ) on each day. The bucks were used in previous semen studies and were accustomed to the collection routine.

Six feral does used as teasers were maintained in oestrus by i.m. injection of $150 \mu \mathrm{g}$ oestradiol benzoate every second day. One teaser doe was restrained in an open-back cradle, allowing the buck to mount freely. The bucks were allowed unrestricted movement around the nearby pens (where the remaining bucks and does in heat were held) until $15 \mathrm{~min}$ before collection. Each buck was then confined in a $3 \mathrm{~m} \times 2 \mathrm{~m}$ pen $2-6 \mathrm{~m}$ from the restrained doe. Sexual drive was measured by the reaction time (seconds), i.e. the time interval between the entry of the buck into the teaser doe's pen and ejaculation. If a buck did not ejaculate within $5 \mathrm{~min}$ after entering the pen, it was removed and the data not used.

Semen volume ( $\mathrm{ml}$ ), sperm concentration (estimated by haemocytometer), sperm motility (score 0 (immotile) to 5 (high)), abnormal spermatozoa (as determined by the method of Dott \& Foster, 1972) and semen colour (intensity of yellow due to riboflavin content; Mendoza et al., 1989) were recorded for each ejaculate.

\section{Dissection and examination of reproductive organs}

The six sexually rested bucks were killed with an intravenous overdose of pentobarbitone sodium (May \& Baker, Australia) the following year in February (early breeding season). Immediately after death, the reproductive tracts were removed, weighed and chilled. The gonadal and extragonadal reserves of spermatozoa were examined according to the method of Amann \& Almquist (1961). The tunica albuginea of the testis and the connective tissue of the epididymis were removed. Each epididymis was sectioned into the caput, corpus and cauda. The parenchyma of the testes and the epididymal sections were weighed, cut into small pieces, finely minced with scissors, and soaked in $0.9 \%$ (w/v) sodium chloride solution. The soaked tissues were homogenized in a Sorvall Omnimixer (Ivan Sorvall Inc., Norwalk, Connecticut, USA) for $30 \mathrm{~s}$ at 2000 r.p.m., $1 \mathrm{~min}$ at 5000 r.p.m. and $15 \mathrm{~s}$ at 7000 r.p.m. The volume of homogenate was measured before filtration through double-layered surgical gauze to remove tissue debris. The filtrate was held at $4^{\circ} \mathrm{C}$ until sperm were counted (not later than $24 \mathrm{~h}$ ). After appropriate dilution of homogenate samples from each portion of the tract, the concentrations of spermatozoa were determined by duplicate haemocytometer counts of sperm heads. The problem of differentiating the sperm cells from tissue debris, as noted for the bull (Amann \& Almquist, 1961), did not arise in this work. It was assumed that in the goat, as in other livestock species, the homogenization of the tissues of the reproductive tract does not cause significant disintegration of sperm heads. The vasa deferentia and ampullae were not examined, but other studies (goats: Fielden \& Berker, 1964; rams: Salamon, 1968; Lino, 1972) indicated that spermatozoa in these parts represent no more than $3 \%$ of the extragonadal reserves.

\section{Statistical analysis}

The data for frequent semen collection were examined by analysis of variance. Differences between the means for the right and left segments of the reproductive tract were analysed by paired $t$-tests. Associations between reproductive tract characteristics were examined by correlation analysis.

\section{Results}

\section{Semen characteristics}

There were significant linear declines in semen volume $(P<0.001)$, sperm concentration $(P<0.05)$ and number of spermatozoa $(P<0.001)$ with consecutive days of collection (Table 1$)$, but only in the case of number of spermatozoa was there a significant quadratic component $(P<0.001)$. Frequent ejaculation within days had an effect only on number of spermatozoa $(P<0.001)$. 
Table 1. Number of ejaculates, semen characteristics and reaction time for Angora bucks used for frequent collection on 5 consecutive days

\begin{tabular}{|c|c|c|c|c|c|}
\hline $\begin{array}{l}\text { Main } \\
\text { effects }\end{array}$ & $\begin{array}{l}\text { Number of } \\
\text { ejaculates }\end{array}$ & $\begin{array}{l}\text { Semen volume } \\
(\mathrm{ml})\end{array}$ & $\begin{array}{l}\text { Concentration } \\
\text { of spermatozoa } \\
\left(\times 10^{9} \mathrm{ml}^{-1}\right)\end{array}$ & $\begin{array}{c}\text { Number of } \\
\text { spermatozoa/buck } \\
\left(\times 10^{9}\right)\end{array}$ & $\begin{array}{l}\text { Reaction } \\
\text { time } \\
(s)\end{array}$ \\
\hline \multicolumn{6}{|l|}{ Day of collection } \\
\hline Day I & 30 & $1.03 \pm 0.06$ & $2.79 \pm 0.21$ & $14.37 \pm 0.27$ & $160 \pm 39 \cdot 8$ \\
\hline 2 & 29 & $0.68 \pm 0.03$ & $2.29 \pm 0.12$ & $7.53 \pm 0.11$ & $337 \pm 121 \cdot 1$ \\
\hline 3 & 27 & $0.71 \pm 0.04$ & $2 \cdot 70 \pm 0 \cdot 15$ & $8.63 \pm 0.15$ & $176 \pm 51 \cdot 5$ \\
\hline 4 & 27 & $0.56 \pm 0.01$ & $2 \cdot 21 \pm 0 \cdot 16$ & $5.57 \pm 0.09$ & $181 \pm 54 \cdot 3$ \\
\hline 5 & 27 & $0.49 \pm 0.03$ & $2.17 \pm 0.08$ & $4.79 \pm 0.08$ & $183 \pm 28.4$ \\
\hline \multicolumn{6}{|c|}{ Ejaculation opportunity } \\
\hline lst & 30 & $0.79 \pm 0.12$ & $2.73 \pm 0.22$ & $10.78 \pm 0.37$ & $176 \pm 48 \cdot 6$ \\
\hline 2nd & 29 & $0.71 \pm 0.08$ & $2.24 \pm 0.21$ & $7.69 \pm 0.23$ & $290 \pm 133.8$ \\
\hline $3 \mathrm{rd}$ & 27 & $0 \cdot 64 \pm 0 \cdot 10$ & $2 \cdot 56 \pm 0.12$ & $7.37 \pm 0.27$ & $176 \pm 37.8$ \\
\hline 4 th & 25 & $0.66 \pm 0.09$ & $2.31 \pm 0.06$ & $6.35 \pm 0.21$ & $174 \pm 43 \cdot 4$ \\
\hline 5 th & 29 & $0.67 \pm 0.08$ & $2.31 \pm 0.27$ & $7.48 \pm 0.24$ & $221 \pm 41.9$ \\
\hline Totals and means & 140 & $0.70 \pm 0.05$ & $2.43 \pm 0.08$ & $7.91 \pm 0.13$ & $209 \pm 20 \cdot 0$ \\
\hline
\end{tabular}

Values are means \pm SEM.

Sperm motility scores were consistently high (score 4 or 5) for all bucks at all collections. There were no sperm abnormalities (cytoplasmic droplets or coiled tails). The colour of the semen varied between successive collections from the individual animals and between animals. Sometimes a bright yellow or light yellow ejaculate was followed by a white one, but there was no consistent pattern.

\section{Reaction time to ejaculation}

There was no significant difference in mean reaction time for the 5 consecutive days or for the five collections within days (Table 1), but only one buck produced 25 ejaculations (maximum possible), two ejaculated 24 times, one ejaculated 23 times and two ejaculated 22 times. There were marked but inconsistent differences between bucks in their reaction time. Ejaculation mostly occurred as soon as the penis was directed into the artificial vagina, but occasionally some bucks mounted several times in a short period yet failed to ejaculate.

\section{Characteristics of reproductive tract}

The mean weights of the paired vesicular and bulbourethral glands and of ampullae were $11 \cdot 4 \pm 0 \cdot 38,3 \cdot 1 \pm 0.35$ and $2 \cdot 5 \pm 0 \cdot 29 \mathrm{~g}$, respectively. The mean lengths and width of the testes were $8.8 \pm 0.19$ and $6.0 \pm 0.08 \mathrm{~cm}$, respectively.

There were no differences in the weights and number of spermatozoa for the left and right testes and epididymides. The mean paired testicular and epididymal weights were $269.1 \pm 12.63$ and $39.7 \pm 0.83 \mathrm{~g}$, respectively, and these parts contained $(22.8 \pm 1.24) \times 10^{9}$ and $(47.8 \pm 3.34) \times 10^{9}$ spermatozoa (i.e. $32 \cdot 3$ and $67.7 \%$ of the total sperm in the reproductive tract) (Table 2 ). The proportion of epididymal spermatozoa in the capita, corpora and caudae were $19 \cdot 7,7 \cdot 2$ and $73 \cdot 1 \%$, respectively.

Significant correlations were found for testicular weight with testicular width and with number of spermatozoa in epididymides, for testicular weight with epididymal weight and for number of spermatozoa in testes with number of spermatozoa in epididymides (Table 3 ). Other significant correlations $(P<0.01)$ not presented in Table 3 were between weight of corpora and weight of caudae with their respective number of spermatozoa $(r=0.74$ and $r=0.54$, respectively), between testicular length and number of spermatozoa in testes $(r=0.55)$ and between 
Table 2. Weights of testes and epididymides and numbers of spermatozoa recovered after slaughter of Angora bucks

\begin{tabular}{|c|c|c|c|c|}
\hline $\begin{array}{l}\text { Portion } \\
\text { of tract }\end{array}$ & $\begin{array}{l}\text { Paired weight } \\
\text { (g) }\end{array}$ & $\begin{array}{c}\text { Total } \\
\text { number of } \\
\text { spermatozoa }\left(\times 10^{9}\right)\end{array}$ & $\begin{array}{l}\% \text { sperm } \\
\text { in portion }\end{array}$ & $\begin{array}{l}\text { Number of } \\
\text { spermatozoa } \mathrm{g}^{-1} \text { tissue } \\
\left(\times 10^{9}\right)\end{array}$ \\
\hline $\begin{array}{l}\text { Testes* } \\
\text { Epididymides }\end{array}$ & $269 \cdot 1 \pm 12 \cdot 63$ & $22 \cdot 8 \pm 1 \cdot 24$ & $32 \cdot 3$ & $(84.6 \pm 6.44) \times 10^{6}$ \\
\hline Capita & $22.5 \pm 0.52$ & $9 \cdot 4 \pm 1 \cdot 19$ & $13 \cdot 4$ & $(418.6 \pm 54.52) \times 10^{6}$ \\
\hline Corpora & $5.5 \pm 0.31$ & $3 \cdot 4 \pm 0 \cdot 22$ & $4 \cdot 8$ & $(621.8 \pm 27.42) \times 10^{6}$ \\
\hline Caudae & $11 \cdot 7 \pm 0.25$ & $35 \cdot 0 \pm 2 \cdot 21$ & $49 \cdot 5$ & $(2992.3 \pm 142.34) \times 10^{6}$ \\
\hline Total for epididymides & $39.7 \pm 0.83$ & $47 \cdot 8 \pm 3 \cdot 34$ & $67 \cdot 7$ & $(1203.7 \pm 85.24) \times 10^{6}$ \\
\hline $\begin{array}{l}\text { Totals and means for } \\
\text { testes and epididymides }\end{array}$ & $308 \cdot 8 \pm 14 \cdot 01$ & $70 \cdot 6 \pm 4 \cdot 09$ & $100 \cdot 0$ & $(228.6 \pm 11.47) \times 10^{6}$ \\
\hline
\end{tabular}

*Without tunica albuginea.

Values are means \pm SEM.

Table 3. Correlation coefficients among reproductive tract characteristics of Angora bucks

\begin{tabular}{lcccccc}
\hline Reproductive tract characteristic & & EWT & TL & TW & NT & NE \\
\hline Testicular weight & (TWT) & $0.42^{*}$ & 0.23 & $0.90^{* *}$ & -0.18 & $0.50^{* *}$ \\
Epididymal weight & (EWT) & & $0.61^{* *}$ & $0.54^{* *}$ & 0.25 & 0.12 \\
Testicular length & (TL) & & & 0.36 & $0.55^{* *}$ & 0.25 \\
Testicular width & (TW) & & & & -0.20 & 0.35 \\
Number of spermatozoa in testes & (NT) & & & & & $0.42^{*}$ \\
Number of spermatozoa in epididymides (NE) & & & & & \\
\hline
\end{tabular}

${ }^{*} P<0 \cdot 05 ;{ }^{* *} P<0.01$.

number of spermatozoa in capita and caudae with number of spermatozoa in epididymides $(r=$ 0.84 and $r=0.96$ ).

\section{Discussion}

Reproductive activity in Angora goats is highly seasonal in response to changes in the photoperiod, and this was demonstrated in the Angora buck by changes in the concentrations of luteinizing hormone and androgens and in testicular size (Ritar, 1991), in the difficulty in collection of semen outside the breeding season and in the freezability of semen (Ritar \& Salamon, 1991). In the present study, semen was therefore collected frequently during peak sexual activity (including output of spermatozoa) at the height of the breeding season in April-May after testes reach their maximum size in mid-February (Ritar, 1991) and when libido is high.

Daily sperm output in the bull (Hale \& Almquist, 1960) and the ram (Salamon, 1962) can be estimated only if a high sexual drive is maintained so that frequent ejaculations deplete the reserves of spermatozoa, and in these species it is possible to collect more than ten ejeculates daily. In this study with Angora bucks, it was possible to collect semen consistently only four or five times daily over 5 days (some bucks did not ejaculate at every opportunity). With such a regimen of semen collection, the output of spermatozoa declined by $67 \%$ over the 5 days and showed a somewhat asymptotic pattern, although the linear component contributed most $(79 \%)$ of the variance. A curvilinear regression for sperm numbers on successive days of frequent collection was also found for Merino rams (Salamon, 1962, 1964a, b). As in the ram, the interval between the last collection 
of one day and the first collection of the next day resulted in only partial replenishment of spermatozoa in the epididymides. It is suggested that for efficient collection of spermatozoa for artificial breeding purposes, the bucks should be given a rest period of 1-2 days between days of intensive semen collection to allow a more complete sperm replenishment.

The number of spermatozoa collected per buck on the first day, $(14.37 \pm 0.27) \times 10^{9}$, represented about $40 \%$ of reserves held in the caudae of the epididymides. Over the 5 days, about $40 \times 10^{9}$ spermatozoa were collected from each buck suggesting an $86 \%$ depletion of epididymal sperm reserves. Evidence from other species also indicates that a residual of $20 \%$ or more of the epididymal reserves remain after frequent collection (bull: Almquist \& Amann, 1961; ram: Salamon, 1964a) although, as postulated by Salamon (1964a), with frequent collection there may be an accelerated epididymal replenishment of spermatozoa. Nevertheless, physical and neural factors may limit the ejaculatory mechanism so that daily sperm output is maintained in equilibrium with the lower sexual drive.

The testes and the epididymides of the Angora bucks were heavier (Table 2) than those of dairy goats (216 g and $39 \mathrm{~g}$, respectively, Fielden \& Berker, 1964) and those of Indian goats ( $69 \mathrm{~g}$ and $9 \mathrm{~g}$, respectively, Jindal \& Panda, 1980), and the number of spermatozoa in the epididymides was proportionally greater in Angoras, although the distribution of sperm reserves in the capita, corpora and caudae (19.7, $7 \cdot 2$ and $73 \cdot 1 \%)$ was similar. The higher number of spermatozoa in the reproductive tract of Angora bucks may be attributable not only to breed differences but also to the fact that they were approaching the peak of seasonal sperm production at the time of slaughter and after a long period of sexual rest. This greatly increases the sperm reserves (Almquist \& Amann, 1961; Fielden \& Berker, 1964) and may explain the higher concentration of sperm in the caudae $\left(2.99 \times 10^{9}\right.$ spermatozoa $\mathrm{g}^{-1}$ tissue $)$ than previously observed for dairy bucks by Fielden $\&$ Berker (1964), who obtained slaughtered goat material late in the breeding season and in the nonbreeding period.

The correlations between testicular and epididymal sperm numbers $(r=0.42)$ and between the paired testes weight and epididymal sperm numbers $(r=0.50)$ suggest that the epididymal reserves depend on the testicular production of spermatozoa, which is the case in sexually rested rams (Ortavant, 1958) but not in bulls (Almquist \& Amann, 1961). Lino (1972) found that, in the ram, there were significant correlations between daily sperm output and the epididymal sperm reserves, between daily sperm output and paired testes weight, and between paired testes weight and epididymal sperm reserves. In this study, there was much less variation in characteristics of the reproductive tract among the Angora bucks (for example, epididymal reserves of spermatozoa ranged only between $36.2 \times 10^{9}$ and $58.5 \times 10^{9}$ ) than that reported by Jindal \& Panda (1980), which may explain our lower correlations between characteristics. Indeed, there was a poor and negative correlation between testicular weight and number of spermatozoa in the testes.

The daily production of spermatozoa may be estimated by the method of Lino (1972) or of Amann (1970). With the first method, the epididymal reserves $\left(47 \cdot 8 \times 10^{9}\right)$ are divided by the transit time of sperm through the genital tract (12 days for ram: Lino, 1972), and a value of $4.0 \times 10^{9}$ spermatozoa day ${ }^{-1}$ is derived. By adopting the second method, the number of sperm heads in the testicular homogenate $\left(22.8 \times 10^{9}\right)$ is divided by 3.56 (days of duration of spermatids at stages VI to VIII of the seminiferous cycle), which gives an estimated daily sperm production of $6.4 \times 10^{9}$, or $23.8 \times 10^{6}$ spermatozoa $\mathrm{g}^{-1}$ testicular tissue. These estimates are similar and only gross approximations since the transit time of spermatozoa through the genital tract and the duration of spermatids at stages VI to VIII of the seminiferous cycle have not yet been determined for the goat. Nevertheless, they are consistent with the daily output of spermatozoa which appeared to approach a plateau on the last day of frequent collection.

We thank A. Souter for technical assistance. A. J. Ritar was supported by a University of Sydney Postgraduate Studentship. 


\section{References}

Almquist, J.O. \& Amann, R.P. (1961) Reproductive capacity of dairy bulls. II. Gonadal and extragonadal sperm reserves as determined by direct counts and depletion trials; dimensions and weight of genitalia. Journal of Dairy Science 44, 1668-1678.

Amann, R.P. (1970) In The Testis (vol. 1), p. 433. Eds A. D. Johnson, W. R. Gomes \& N. L. VanDemark. Academic Press, NY.

Amann, R.P. \& Almquist, J.O. (1961) Reproductive capacity of dairy bulls. I. Technique for direct measurement of gonadal and extra-gonadal sperm reserves. Journal of Dairy Science 44, 1537-1543.

Dott, H.M. \& Foster, G.C. (1972) A technique for studying the morphology of mammalian spermatozoa which are eosinophilic in a differential 'live/dead' stain. Journal of Reproduction and Fertility 29, $443-445$

Fielden, E.D. \& Berker, C.A.V. (1964) Semen collection studies and sperm reserves in the goat. Proceedings of Sth International Congress of Animal Reproduction and Artificial Insemination. Vol. 3, 488-497.

Hale, E.B. \& Almquist, J.O. (1960) Relation of sexual behaviour to germ cell output in farm animals. Journal of Dairy Science Supplement 43, 145-169.

Jindal, S.K. \& Panda, J.N. (1980) Epididymal sperm reserves of the goat (Capra hircus). Journal of Reproduction and Fertility 59, 469-471.

Kennelly, J.J. \& Foote, R.H. (1964) Sampling boar testis to study spermatogenesis quantitatively and to predict sperm production. Journal of Animal Science 23, $160-167$.

Lino, B.F. (1972) The output of spermatozoa in rams. II. Relationship to scrotal circumference, testis weight, and the number of spermatozoa in different parts of the urogenital tract. Australian Journal of Biological Sciences 25, 359-366.

Lino, B.F. \& Braden, A.W.F. (1972) The output of spermatozoa in rams. I. Relationship with testicular output of spermatozoa and the effect of ejaculations. Australian Journal of Biological Sciences 25, $351-358$.
Mendoza, G., White, I.G. \& Chow, P. (1989) Studies of chemical components of Angora goat seminal plasma. Theriogenology 32, 455466 .

Orgebin-Crist, M.C. (1968) Gonadal and epididymal sperm reserves in the rabbit: estimation of the daily sperm production. Journal of Reproduction and Fertility 15, 15-25.

Ortavant, R. (1958) Le cycle spermatogenetique chez le belier. Doctor of Science Thesis, University of Paris, France.

Ortavant, R. (1959) Spermatogenesis and morphology of the spermatozoan. In Reproduction in Domestic Animals, 2nd edn, pp. 1-50. Eds H. H. Cole \& P. T. Cupps. Academic Press, NY.

Ritar, A.J. (1991) Seasonal changes in LH, androgens and testes in the male Angora goat. Theriogenology 36, 959-972.

Ritar, A.J. \& Salamon, S. (1991) Effects of month of collection, method of processing, concentration of egg yolk and duration of frozen storage on viability of Angora goat spermatozoa. Small Ruminant Research 4, 29-37.

Salamon, S. (1962) Studies on the artificial insemination of Merino sheep. III. The effect of frequent ejaculation on semen characteristics and fertilizing capacity. Australian Journal of Agricultural Research 13, $1137-1150$.

Salamon, S. (1964a) The effect of nutritional regimen on the potential semen production of rams. Australian Journal of Agricultural Research 15, 645-656.

Salamon, S. (1964b) The effect of frequent ejaculation in the ram on some semen characteristics. Australian Journal of Agricultural Research 15, 950-960.

Salamon, S. (1968) Viability and morphology of ram spermatozoa in the ligated epididymis. Australian Journal of Biological Sciences 21, 769-780.

Weisgold, A.D. \& Almquist, J.O. (1979) Reproductive capacity of beef bulls. VI. Daily spermatozoal production, spermatozoal reserves and dimensions and weight of reproductive organs. Journal of Animal Science 48, 351-358.

Received 2 February 1991 